\title{
REGULATION OF ACCESS TO POSTAL INFRASTRUCTURE IN POLAND ON THE EXAMPLE OF SELECTED EUROPEAN UNION COUNTRIES
}

\author{
ANNA DRAB-KUROWSKA, ${ }^{1}$ MICHAŁ KUŚCIŃSKI ${ }^{2}$ \\ ${ }^{1}$ University of Szczecin, POLAND \\ e-mail: anna.drab@wzieu.pl \\ ${ }^{2}$ The Jacob of Paradies University, POLAND \\ e-mail: michal.kuscinski@wp.pl
}

\section{RECEIVED \\ ACCEPTED \\ JEL \\ CLASSIFICATION \\ KEYWORDS}

ABSTRACT
10 May 2018

20 September 2018

L87, L97

postal market, regulation, postal services

The purpose of the article is to attempt to recognize the problem which is access to postal infrastructure in the context of selected European countries. The article presents the following research hypothesis - Increasing the use of postal infrastructure will allow for more effective management and an increase of competitiveness of postal operators. In reference to the assumed goal and adopted hypothesis, the following research question was posed in the article - which model of cooperation in the field of access to postal infrastructure is appropriate? In an attempt to answer the question, the article refers first to the situation on the postal market in Poland. Next, it concentrates on the essence of the postal infrastructure, referring to the basic elements. In addition, it focuses on presenting elements with which the postal operators can achieve a synergy effect. The key element of the article is the presentation of proposals for measures to increase the efficiency in the provision of postal infrastructure.

\section{Introduction}

In recent years, significant development of postal markets has been observed. This is the effect of changing consumer preferences and the development of modern technologies. Along with technological development, there is a change in the behavior of prosumers - from prosumers whose activity is controlled by companies who give them individual elements so that they can make or modify a product according to their own preferences - to prosumers 
whose activity elude from the control of companies; when consumers on the basis of products create new solutions according to their own ideas and only later do companies find out what consumers do with their products (BudziewiczGuźlecka, 2017). As a result of e-substitution and the economic crisis in the area of traditional postal services (Crew, Brennan, 2014, p. 17), clear downward trends in revenues from activities in the area of letter post in most EU countries, including Poland, are noticed. On the other hand, the importance of package services for business and consumers due to e-commerce (Hearn, 2017; Marcus, Petropoulos, 2017) increases. The purpose of the article is to attempt to recognize the problem which is access to postal infrastructure in the context of selected European countries. The article presents the following research hypothesis - Increasing the use of postal infrastructure will allow for more effective management and an increase of competitiveness of postal operators. In reference to the assumed goal and adopted hypothesis, the following research question was posed in the article - which model of cooperation in the field of access to postal infrastructure is appropriate? In an attempt to answer the question, the article refers first to the situation on the postal market in Poland. Next, it concentrates on the essence of the postal infrastructure, referring to the basic elements. In addition, it focuses on presenting elements with which the postal operators can achieve a synergy effect. The key element of the article is the presentation of proposals for measures to increase the efficiency in the provision of postal infrastructure.

\section{The postal services market in Poland}

Postal services, despite growing competition from modern forms of electronic communication and the emergence of new telecommunications products (Budziewicz-Guźlecka, 2009), are still a significant and necessary tool for exchanging information and goods, providing society with important social and economic benefits. The total value of the Polish postal services market in 2016 amounted to PLN 7,649.98 million. As at the end of 2016, there were 291 entities in the register of postal operators, however, a significant part did not undertake the postal activity or suspended it. 151 postal operators (Raport..., 2017) were active in the provision of postal services. For several years, the Polish postal market has also been the place of liberalization changes resulting from three subsequent directives of the European Parliament and the Council (Tochkov, 2015). The guidelines included in the European Union directives have been implemented into the Polish legal order by the Postal Law Act (Tochkov, 2015). In the light of this Act, of great importance to the Polish postal services market is article 71 which defines the concept of a designated operator, ${ }^{1}$ elected for a period of 10 years by decision of the President of the Office of Electronic Communications (UKE) from among the postal operators selected in a competition announced by the President of UKE. The competition may be entered by any postal operator conducting postal activity on the basis of an entry in the register, who has economic and technical capacity including at least:

- A network of post offices,

- Network of distribution centres,

- Means of transport,

- Organization of the enterprise,

${ }^{1}$ A designated operator in accordance with article 46 of the Postal Law Act is obliged, among others to provide universal services in a uniform manner in comparable conditions, at affordable prices, while ensuring distribution of post offices and postal mailboxes throughout the whole country, with postage flow time indicators at a frequency ensuring at least one emptying of the outgoing mailbox and delivery of postal items at least every working day and not less than 5 days a week, excluding public holidays, in a manner enabling the sender to obtain a document confirming the receipt of a registered consignment. 
- Financial liquidity - enabling implementation of tasks of the designated operator.

In 2015, in Poland, the competition for the postal designated operator was won by Poczta Polska SA who will provide universal services until 2025.

\section{Post offices as a basic element of the postal network in Poland against the background of selected EU countries}

Postal designated operators in all European Union countries pursuant to the provisions of Directive 2008/6/ EC have a legal obligation to make available to other operators selected elements of their own postal infrastructure, as is apparent from Article 11a. In the remaining scope, the Second Postal Directive does not, however, introduce specific harmonization provisions, but leaves it to the discretion of the Member States how to regulate this access depending on the needs of the domestic postal market. These regulations are different because Postal laws adopted in individual countries are of a comprehensive nature. This means that access to the postal infrastructure must be considered jointly, inter alia, with such stipulations as the question of the provision and financing of the universal service.

The starting point for the analysis of the network of postal operators is the reference to post offices, which constitute a basic element of the postal network. Based on the data obtained ${ }^{2}$, it was demonstrated that in the years 2008-2016 the total number of post offices in the countries surveyed increased by $3.1 \%$ on average each year. In the case of universal service providers, this dynamic was at the level of approx. $0.6 \%$ each year, while in the case of other postal operators, the growth was at the level of about $8.2 \%$ annually. This trend was disturbed in 20152016 when there was a clear drop in post offices in the group of other postal operators. The main reason was the decrease in the number of these facilities in Poland (from 16,908 in 2015 to 8,616 in 2016). This was due to the fact that in 2016 a key competitor of Poczta Polska SA, after losing the contract for the delivery of court correspondence, withdrew from the market of letter-post items, and most of its nationwide outlets were liquidated. Nevertheless, in some countries, the number of post offices has increased significantly, as in countries, such as Germany (92.3\% 22), Estonia (61.8\%) and Denmark (45.5\%). Figure 1 shows the number of post offices of universal service providers and other postal operators in the years 2008-2016 in selected European countries.

An essential element of the postal infrastructure, which has been gaining more and more importance in recent years, is the parcel lockers system. Parcel lockers is a system of automatic postal boxes (or postal terminals) used to send and receive parcels. These devices constitute a significant support for the postal infrastructure of a postal operator, as they are located in public places, easily accessible 24 hours a day. Analysis of the elements of postal infrastructure including parcel lockers revealed that not all national regulatory authorities monitor this element of infrastructure. ${ }^{3}$ However, the upward trend clearly emerges; their number is growing as expected. The exceptions are declines in the Czech Republic, where the number of parcel lockers of universal service providers has dropped by $50 \%$ and in the Netherlands, where there was a $21 \%$ decrease for parcel lockers of other universal service

2 The study includes data obtained from universal service providers and other postal service providers for the following countries: BG, CY, CZ, DE, EE, EL, IS, IT, FY, HR, HU, LT, MT, PL, PT, RO, RS, SI, SK. It should be pointed out that the data of countries where information on post offices is available only to universal service providers are not taken into account.

${ }^{3}$ Only one-third of the countries surveyed: BE, CY, CZ, DK, EE, ES, FI, HU, IS, LT, NL, PL and SI, collect some data on parcel lockers. On the other hand, the national regulatory authorities of some countries $(\mathrm{CH}, \mathrm{HR}, \mathrm{IT}, \mathrm{MT}, \mathrm{SK} 23)$, even those authorized to collect data related to parcel lockers, did not collect this information until 2016. 
providers. It is necessary to clarify the situation on the Polish postal market. Despite the fact that Poland has this element of postal infrastructure, the presented statistics indicate the lack of this form of postal infrastructure for other providers of universal services in the years 2015-2016. It results from the fact that the network of parcel lockers was sold (and then transferred back) to an entity that is not a postal operator, therefore the national regulatory authority was unable to collect data on this entity. Table 1 presents the number of parcel lockers for universal service providers and other postal operators.

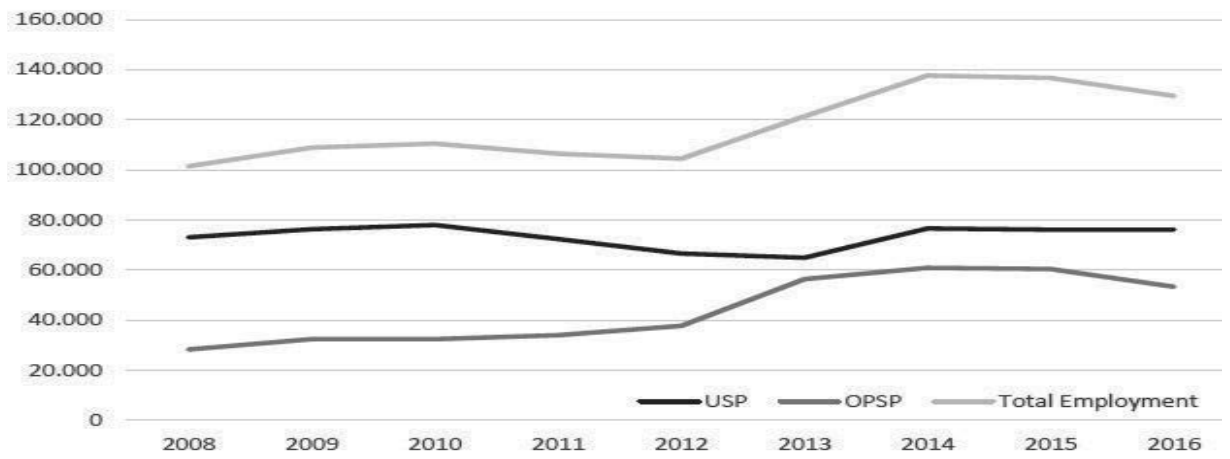

Figure 1. The total number of post offices of universal service providers and other postal operators in 2008-2016 in selected countries

Source: ERGP (17) 36, p. 75.

Table 1. Parcel lockers of universal service providers and other postal operators in the years 2013-2016

\begin{tabular}{|c|c|c|c|c|c|c|c|c|c|c|}
\hline & & & $/$ Incum & & & & Other & I servic & jiders & \\
\hline & 2013 & 2014 & 2015 & 2016 & $\begin{array}{c}\text { var. } \\
2013 / 2016 \\
(\%)\end{array}$ & 2013 & 2014 & 2015 & 2016 & $\begin{array}{c}\text { var. } \\
2013 / 2016 \\
(\%)\end{array}$ \\
\hline Belgium & n.a. & n.a. & 150 & 150 & 0 & n.a. & n.a & n.a. & n.a. & \\
\hline Cyprus & n.a. & n.a. & 2 & 3 & & 0 & 0 & 0 & 0 & \\
\hline Czech Republic & & 10 & 15 & 5 & -50.0 & 0 & 0 & 0 & 32 & \\
\hline Denmark & 445 & 467 & 468 & 469 & 5.0 & n.a. & n.a. & n.a. & n.a. & \\
\hline Estonia & 79 & 98 & 104 & 124 & 57.0 & 81 & 83 & 85 & 111 & 37.0 \\
\hline Finland & 307 & 459 & 482 & 179 & 56.0 & n.a. & n.a. & n.a. & n.a. & \\
\hline Greece & & & & & & n.a. & n.a. & n.a. & 256 & \\
\hline Hungary & n.a. & n.a. & 50 & 50 & 0 & n.a. & n.a. & 152 & 138 & -9.2 \\
\hline Iceland & n.a. & n.a. & 8 & 8 & 0 & n.a. & n.a. & n.a. & & \\
\hline Lithuania & n.a. & n.a. & 0 & 0 & 0 & n.a. & 121 & 131 & 184 & 52.1 \\
\hline Poland & 34 & 117 & 120 & 120 & 253.0 & 283 & 100 & & & \\
\hline The Netherlands & & & 8 & 10 & 25.0 & & & 33 & 26 & -21.0 \\
\hline Slovenia & & & 24 & & & & & & 45 & \\
\hline Spain & & & 403 & 2,305 & 472.0 & n.a. & n.a. & n.a. & n.a. & \\
\hline
\end{tabular}

n.a. - not applicable.

Source: ERGP PL (17) 38. 
The number of parcel lockers increased significantly in some countries, especially in Spain and Poland. In Spain, the impressive growth in the number of parcel lockers in 2015-2016 results from the strategy of a universal service provider who in 2015-2016 massively installed automatic postal boxes. At the end of 2016, the number of parcel lockers in Spain was the highest in comparison to other surveyed countries and amounted to 2,305. It should be pointed out that this element of postal infrastructure began to play a significant role especially in the context of the development of electronic commerce, both B2B and B2C dimension. Due to the increasing use of the Internet, as well as the growing number of entities making online payments, there was a certain gap in the market, which was now filled by parcel lockers (Ciepaj, 2012). Interestingly, in Poland in 2016 alternative operators had 8,615 outlets, while the designated operator had 7,497 post offices. It results, among other things, from the fact that, to an ever greater extent, postal services are provided with the use of machines for postal customer service. ${ }^{4}$

\section{Regulation of access to the postal network}

Access to the postal network is one of the obligations of the universal service provider imposed to ensure competition in the postal market. An analysis is necessary to indicate what limitations appear in access to the postal network on selected European postal markets. It should be pointed out that depending on the situation on the postal market and national legislation, access to the network is perceived in various ways.

Table 2. The scope of access to the postal network - regulations

\begin{tabular}{|c|c|c|c|c|}
\hline & \multicolumn{3}{|c|}{ The scope of access to the network in legislation } & \multirow[b]{2}{*}{ Access to postal network in practice } \\
\hline & $\begin{array}{l}\text { universal } \\
\text { services }\end{array}$ & $\begin{array}{l}\text { outside of universal } \\
\text { services }\end{array}$ & other & \\
\hline 1 & 2 & 3 & 4 & 5 \\
\hline Austria & NO & NO & $\begin{array}{l}\text { In Austrian Postal Act the rules } \\
\text { are in force regarding postal code, } \\
\text { return and redirection services }\end{array}$ & n.a. \\
\hline Belgium & YES & NO & & $\begin{array}{l}\text { On the Belgian market, many operators have access to } \\
\text { commercial tariffs of the designated operator by the contract }\end{array}$ \\
\hline Bulgaria & YES & YES & & n.a. \\
\hline Croatia & YES & NO & & $\begin{array}{l}\text { In order to gain access to the postal network, the universal } \\
\text { service provider uses a reference offer for access with the } \\
\text { same access conditions for other postal service providers, } \\
\text { consolidators and natural persons. In Croatia, business users/ } \\
\text { large postal companies do not use the access to the postal } \\
\text { network. The rules regarding offers and the control of access } \\
\text { prices to the postal network are not the same as special tariffs } \\
\text { and conditions applicable to business users/large customers }\end{array}$ \\
\hline $\begin{array}{l}\text { Czech } \\
\text { Republic }\end{array}$ & \multicolumn{3}{|c|}{$\begin{array}{l}\text { The Postal Act states that the universal service provider is obliged to } \\
\text { allow access to the "delivery service at addresses given on postal items" } \\
\text { as part of the general obligation to provide access to postal infrastructure }\end{array}$} & n.a. \\
\hline Denmark & \multicolumn{3}{|c|}{$\begin{array}{l}\text { The universal service provider is required to provide access to mailboxes } \\
\text { and address bases }\end{array}$} & \\
\hline France & $\begin{array}{l}\text { No network } \\
\text { access }\end{array}$ & & & $\begin{array}{l}\text { The universal service provider does not provide access to the } \\
\text { network. It offers a mass mail tariff, which each player can use } \\
\text { depending on the terms of the offer }\end{array}$ \\
\hline
\end{tabular}

${ }^{4}$ Raport... (2017), p. 5. 


\begin{tabular}{ccccc}
\hline 1 & 2 & 3 & 4 & 5 \\
\hline Germany & YES & $\begin{array}{c}\text { No-no sectoral } \\
\text { rules, competition } \\
\text { law }\end{array}$ & NO & $\begin{array}{l}\text { There are many companies - mainly acting as consolidators and } \\
\text { end competitors who seek access to postal infrastructure for } \\
\text { complementary regions and areas where they are active - after } \\
\text { concluding contracts for access to sorting department }\end{array}$ \\
\hline Lungary & YES & No & No entities applying for access \\
\hline & NO & YES & $\begin{array}{l}\text { The universal service provider publishes virtually the same offers } \\
\text { for postal service providers (for access to the postal network) } \\
\text { and for contract customers (companies, mass envelopes or mail } \\
\text { consolidators). There are currently } 9 \text { agreements on access to } \\
\text { the postal network in Lithuania }\end{array}$ \\
\hline
\end{tabular}

The legislation provides for commercial negotiations on access to the network between postal operators, including universal service providers, and for the market regulator to impose on universal service providers the network access obligation.

Holland n.a. YES

The designated operator in Poland is only required to provide operators with access to postal infrastructure components: post-office boxes, own

Poland mailboxes, a zip code system identifying areas for postal items delivery and a database with information on address changes for the purpose of re-addressing postal items

The Portuguese Postal Law states that the universal service provider

Portugal ensures access to their network, and the universal service network means the postal network on which the universal service is provided

\begin{tabular}{ll}
\hline Romania & YES \\
\hline Serbia & YES \\
\hline Slovakia & YES \\
\hline
\end{tabular}

Slovenia NOS NO

\begin{tabular}{ll}
\hline & The postal act includes access \\
& to other infrastructures, such as \\
a postal code system, address & database, post office boxes, \\
Spain NO $\quad$ delivery boxes, change of address \\
information, redirection service \\
and sender return service
\end{tabular}

Great $\quad$ YES
Britain

n.a - not applicable.

Source: ERGP PL (17) 38.
The national regulatory authority believes that PostNL has a significant market position and should, therefore, provide access to its network under other obligations on the basis of transparency and non-discrimination in order to mitigate the potential damage to competition resulting from its significant market position

In 2016, the universal service provider published an access offer, which is currently being analyzed. In addition, the national regulatory authority is currently resolving a dispute between the universal service provider and other postal operators

In Serbia, access is defined in the contract between the universal service provider and the applicant/recipient of access to the network (no contract has yet been concluded)

No postal operator providing substitute services for universal service has yet asked for access to the network

If the interchangeable service provider requests access, and the access agreement is not concluded within four months, the provider of interchangeable services may require the national regulatory authority to decide on access

Spanish law provides access to universal services and other infrastructures. In practice, the universal service provider ensures network access to alternative operators through mass reception centres in accordance with the terms "negotiated" with them

Royal Mail provides access to the bottom of its network at the entry point to internal shipping centres. Here the final sorting of postal items takes place, and then the mail is forwarded to the Royal Mail delivery offices to be delivered to the destination. The regulatory office has recently carried out a review of postal regulations, including the access framework 
In most of the countries surveyed, ${ }^{5}$ it was found that the universal service provider ensures access to its postal network to other postal operators. In Spain, the universal service provider is required to draw up a standard contract for access to the postal network, which will be approved in advance by the national regulatory authority and published both on the website of the operator and the national regulatory authority itself. Similarly, in the Czech Republic and Croatia, the universal service provider is required to publish a reference offer. It should be pointed out that representatives of ten countries with negative responses stated that the universal service provider does not provide access to the postal network. In France, the universal service provider does not provide access to the network, but offers tariffs for wholesale postal items, which each market participant may use depending on the terms of the offer. An interesting solution occurs in Slovenia. If the service provider requests access and the access agreement is not concluded within four months, the postal operator may require the national regulatory authority to decide on access.

\section{The access regulation model for postal infrastructure}

An analysis of European legislation has shown that different models of providing the postal network are used. By examining individual markets, three models of cooperation between postal operators can be distinguished, as shown in Figure 2.

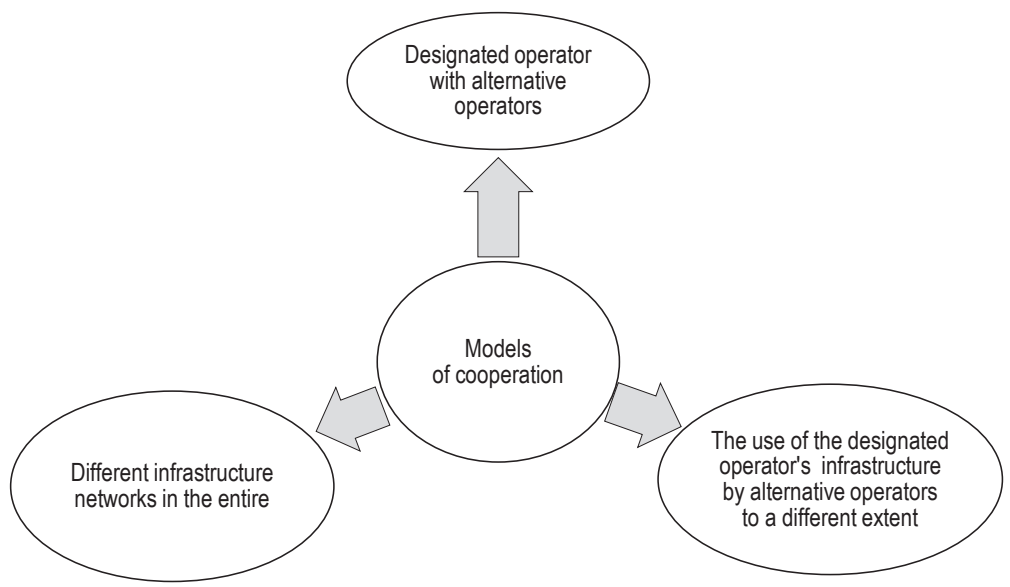

Figure 2. Models of cooperation within the framework of access to postal infrastructure

Source: own study.

From the models of postal infrastructure provisioning shown in Figure $x$, a solution that would ensure that non-public operators use the designated operator's infrastructure in a different scope is considered to be justified. On the other hand, elements of the postal network whose sharing is not an obligation resulting from the provisions should be made available on a commercial basis. It should be considered important to establish the possible

\footnotetext{
${ }^{5}$ In seventeen out of twenty-seven subjects.
} 
scope of cooperation between operators, and appropriate prices that will ensure the profitability of the service and will allow for avoiding disputes. An account of the costs incurred and the benefits obtained will have a key role in deciding whether to share the network. All postal operators should strive for solutions favouring the synergy effect of both parties, while avoiding the situation where competing entities will use access to its infrastructure to maximize their chances of winning and become a leading operator, limiting the role of a designated operator who is a universal service provider, to the role of a subcontractor. Figure 3 presents elements affecting the achievement of the synergy effect that both the designated operator and alternative operators face.

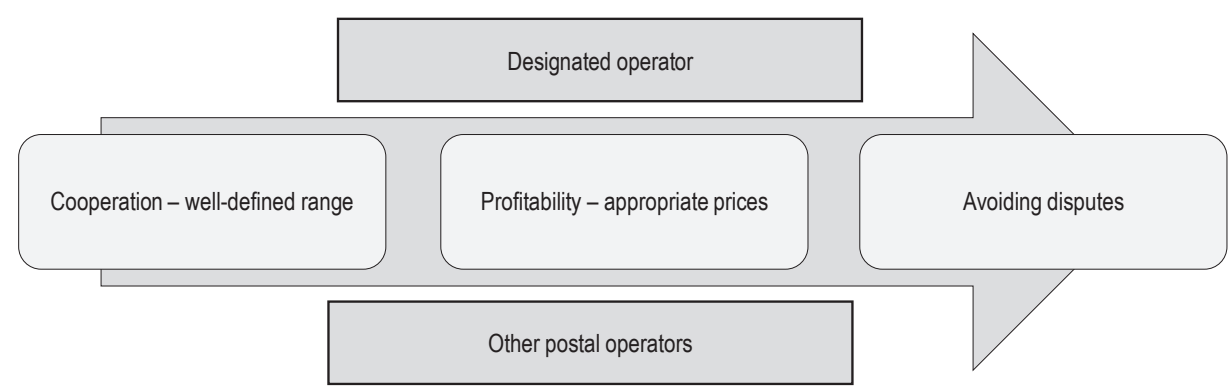

Figure 3. Elements influencing the achievement of the synergy effect

Source: own study.

The application of the recommendations presented in Figure $\mathrm{x}$ will allow postal operators to effectively use their infrastructure. In addition, it should be emphasized that the designated operator has a chance to obtain additional revenues resulting from cooperation with other entities operating on the postal market.

\section{Conclusions}

The analysis of the European postal market has shown that there is still a need for administrative control of access to postal infrastructure, especially where it is still not strictly defined in the legal framework, and there is a clear limitation in the context of the functioning of competitive entities. In Poland, alternative operators expand their network mainly with a model of external collection points and through a network of parcel lockers. Poczta Polska, in accordance with the new strategy for 2018-2022, gradually develops its own network of post offices, but also, just like the market does, expands the click \& collect network, i.e. external collection points for e-commerce clients. However, support by the regulator is necessary in order to promote the development of competition in the postal sector.

\section{References}

Budziewicz-Guźlecka, A. (2009). Nowy produkt telekomunikacyjny w aspekcie konwergencji. Zeszyty Naukowe Uniwersytetu Szczecińskiego. Ekonomiczne Problemy Usług, 35/2, 519-530.

Budziewicz-Guźlecka, A. (2017). Role of the Sharing Economy in the Contemporary Economy. Ekonomiczne Problemy Usług, 1 (126), 27-36.

Ciepaj, E. (2012). Paczkomaty - innowacyjne rozwiązanie na rynku usług logistycznych. Logistyka, 2, 445-455. 
Drab-Kurowska, A. (2018). The role of the national postal operator in the context of e-administration development-example of Poland. In Economic and Social Development (Book of Proceedings), 27th International Scientific Conference on Economic and.

Crew, M.A., Brennan, T.J. (eds.) (2014). The Role of the Postal and Delivery Sector in a Digital Age. Edward Elgar Publishing.

ERGP (17) 36. Report on core indicators for monitoring the European postal market, 15 December 2017, p. 75.

ERGP PL (17) 38. Sprawozdanie w sprawie zaleceń i najlepszych praktyk w zakresie regulacji dostępu do sieci pocztowej.

Hearn, J. (2017). Protecting Consumers Using Postal and E-Commerce Delivery Services in Competitive European Markets. In: The Changing Postal and Delivery Sector (pp. 127-137). Springer, Cham.

Khazabi, M. (2017). Postal service markets: an international comparison analysis. Journal of Public Affairs, 17 (3).

Marcus, J.S., Petropoulos, G. (2017). E-commerce in Europe: Parcel delivery prices in a digital single market. In: The Changing Postal and Delivery Sector (pp. 139-159). Springer, Cham.

Raport o stanie rynku pocztowego w 2016 roku (2017). Warszawa: UKE.

Tochkov, K. (2015). The efficiency of postal services in the age of market liberalization and the internet: Evidence from Central and Eastern Europe. Utilities Policy, 36, 35-42.

Cite this anticle aS: Drab-Kurowska, A., Kuściński, M. (2018). Regulation of access to postal infrastructure in Poland on the example of selected European Union countries. European Journal of Service Management, 3 (27/1), 71-79. DOI: 10.18276/ejsm.2018.27/1-09. 